\title{
A Nutrient Mixture Inhibits MMP Secretion, Invasion, Growth, and Induction of Apoptosis in Human Tongue Cancer Cell Line SC-255
}

\author{
M. Waheed Roomi, Nusrath W. Roomi, Bilwa Bhanap, Aleksandra Niedzwiecki*, Matthias Rath \\ Dr. Rath Research Institute, Oncology Division, Santa Clara, USA \\ Email: *author@drrath.com
}

Received September 18, 2013; revised October 18, 2013; accepted October 25, 2013

Copyright (C) 2013 M. Waheed Roomi et al. This is an open access article distributed under the Creative Commons Attribution License, which permits unrestricted use, distribution, and reproduction in any medium, provided the original work is properly cited.

\begin{abstract}
A majority of oral cancers is squamous cell carcinoma and tongue carcinomas comprise $30 \%$ of all oral cancers. Phytochemicals, herbal and dietary antioxidants have been reported to prevent cancers. A nutrient mixture containing, ascorbic acid, lysine, proline and green tea extract, among other nutrients, has previously been shown to exhibit a broad spectrum chemo preventative and therapeutic anti-cancer properties in a number of cell lines. In a recent study, we found that the nutrient mixture significantly inhibited acetaminophen induced hepatic and renal toxicity, and it suppressed carbon tetrachloride induced hepatic toxicity in ICR mice as well. This study was undertaken to determine if the nutrient mixture is useful in inhibiting various parameters of cancer progression on human tongue cancer cell line SC-255. SC-255 cells were grown in a Dulbecco's Eagle medium and treated with the nutrient mixture at 0, 10, 50, 100, 500 and $1000 \mu \mathrm{g} / \mathrm{ml}$, in triplicate. The nutrient mixture exhibited $20 \%$ and $30 \%$ toxicity at 500 and $1000 \mu \mathrm{g} / \mathrm{ml}$, respectively. Zymography demonstrated the expression of MMP-2 and MMP-9; and PMA treatment further enhanced MMP-9 activity. The nutrient mixture inhibited the secretion of MMP-2 and MMP-9 in a dose-dependent fashion with a total inhibition at $500 \mu \mathrm{g} / \mathrm{ml}$. Matrigel invasion was significantly reduced by $40 \%, 80 \%$ and $100 \%$ at 100,500 and 1000 $\mu \mathrm{g} / \mathrm{ml}$, respectively. The nutrient mixture also inhibited cell migration and induced apoptosis in a dose response fashion. Thus, the nutrient mixture may have a potential in the tongue cancer treatment.
\end{abstract}

Keywords: Oral Cancer; Nutrient Mixture; MMP; Apoptosis

\section{Introduction}

A vast majority of oral cancers is squamous cell carcinoma of the tongue and tongue carcinomas comprise $30 \%$ of all oral cancers. Men are at double the risk of developing oral cancer and dying from it as compared to women. Tobacco use and alcohol consumption have been identified as major risk factors of oral cancer in $75 \%$ of the cases [1-3]. Moreover, the recent rise in Human Papilloma Virus (HPV) infections has also been identified as a risk factor in the malignant transformation of the oral mucosa [4-6]. Dietary factors like the chewing of areca (betel) nut [7], poor oral hygiene and malnutrition [8-10] have been associated with oral lesions with the potential for malignant transformation.

According to the American Cancer Society's 2013 estimates, cancer of the oral cavity and pharynx is expected to affect 36,000 individuals [11]. In the United States, the

*Corresponding author. five-year survival rate of oral cancer is approximately $60 \%$ for all stages, and $82.8 \%$ for local lesions. The survival rate decreases to $51.8 \%$ when cancer metastasizes to the surrounding organs. The survival rate drops to $27.8 \%$ for metastatic cancer [12]. Early detection and recognition of oral premalignant lesions are effective methods in decreasing mortality and morbidity. Many signs of oral cancer are not present in their early development stage [13], with many patients first displaying cancer once it has advanced [14]. Several histo-pathological features such as perineural invasion, lymphocytic response, depth of invasion and distant spread negatively affect the prognosis of oral cancer. Local and distant metastasis occurs through extra capsular extension of cancer cells. Invasion of the tumor capsule leading to distant metastasis is associated with a significant increase in mortality rates [15]. The treatment of tongue cancer is based on the stage of disease. Because extra capsular invasion is a marker for poor prognosis, these patients 
have to undergo toxic chemo and radiotherapy sessions [16]. Since these treatments are associated with poor outcome and severe toxicity, there is an urgent need to develop more efficient and less toxic methods. Interventions targeting the molecular mechanism of extra capsular invasion, which prevent the local and distant spread of cancer cells, could influence the prognosis of oral cancer.

Focusing on common patho-mechanisms of cancer growth, invasion, and metastasis; Rath and Pauling [17] developed a new approach using micronutrients to control cancer by controlling invasive parameters of cancer progression (i.e. MMPs and enhancing the structural stability of the extracellular membrane). Utilizing the principles of synergy, we formulated a nutrient mixture (NM) including lysine, proline, ascorbic acid and green tea extract, and others. The NM has shown a broad spectrum of anti-cancer effects, in vivo and in vitro, against a number of cancer cell lines [18-21]. In the current study, we investigated the effect of the NM on toxicity, cell migration, invasion, MMP expression, apoptosis, and morphology on human tongue cell line SC-255. We hypothesized that the NM would significantly inhibit growth, MMP expression, invasion, and induce apoptosis of the SC-255 cancer cell line.

\section{Materials and Methods}

\subsection{Composition of the Nutrient Mixture}

The composition of the nutrient mixture includes the following: Vitamin $\mathrm{C}$ (as ascorbic acid and as $\mathrm{Mg}, \mathrm{Ca}$ and palmitate ascorbate) $710 \mathrm{mg}$; L-lysine $1000 \mathrm{mg}$; LProline $750 \mathrm{mg}$; L-Arginine $500 \mathrm{mg}$; N-Acetyl Cysteine $200 \mathrm{mg}$; Standardized Green Tea Extract (80\% polyphenol) $1000 \mathrm{mg}$; Selenium $30 \mu \mathrm{g}$; Copper $2 \mathrm{mg}$; and Manganese $1 \mathrm{mg}$.

\subsection{Cell Line and Culture}

Tongue cancer cell line SC-255 from American Type Culture Collection (ATCC, Rockville, MD) was grown in modified Dulbecco's Eagle medium supplemented with $10 \%$ fetal bovine serum, $100 \mathrm{U} / \mathrm{ml}$ penicillin and $100 \mu \mathrm{g} / \mathrm{ml}$ streptomycin (Gibco BRL, Long Island, NY) in 24-well tissue culture plates (Costar, Cambridge, MA). Cells were incubated with $1 \mathrm{ml}$ of media at $37^{\circ} \mathrm{C}$ in a tissue culture incubator equilibrated with $95 \%$ air and $5 \%$ $\mathrm{CO}_{2}$. At near-confluence, the wells were treated with the $\mathrm{NM}$, dissolved in the media and tested with the nutrient mixture at the following doses (in triplicate): $0,10,50$, 100,500 and $1000 \mu \mathrm{g} / \mathrm{ml}$. Cells were also treated with PMA (100 ng/ml) to induce MMP-9 secretion. The plates were then returned to the incubator.

\subsection{MTT Assay}

Cell toxicity was evaluated by MTT assay, a colorimetric assay based on the ability of viable cells to reduce a soluble yellow tetrazolium salt [3-(4,5-dimethylthiazol-2-yl) 2,5-diphenyl tetrazilium bromide] (MTT) to a blue formazan crystal by mitochondrial succinate dehydrogenase activity of viable cells. This test is a good index of mitochondrial activity and thus of cell viability. After a 24-hour incubation period with different doses of the NM, cells were washed with phosphate buffered saline (PBS) and $500 \mu \mathrm{l}$ of MTT (Sigma\#M-21280.5 mg/ml in media was added. After the addition of MTT, plates were covered and returned to the $37^{\circ} \mathrm{C}$ incubator for 2 hours (optimal time for formazan product formation). Following incubation, the supernatant was carefully removed from the wells, the formazan product was dissolved in $1 \mathrm{ml}$ of DMSO, and absorbance was measured at $570 \mathrm{~nm}$ in a Bio-Spec 1601 Shimadzu spectrometer. The OD570 of the DMSO solution in each well was considered to be proportional to the number of cells. The OD of the control (treatment without supplement) was considered $100 \%$.

\subsection{Gelatinase Zymography Enzyme Activity Assay}

Gelatinase zymography was performed in a $10 \%$ Novex Pre-Case SDS Polyacrylamide Gel (Invitrogen Corporation) in the presence of $0.1 \%$ gelatin under non-reducing conditions. Culture media $(20 \mathrm{ml})$ was mixed with a sample buffer and loaded for SDS Polyacrylamide Gel Electrophoresis (SDS-PAGE) with a tris glycine SDS buffer per Novex, the manufacturer. Samples were not boiled before electrophoresis. Following electrophoresis, the gels were washed twice in a $2.5 \%$ Triton X-100 for 30 minutes at room temperature to remove SDS. The gels were then incubated at $37^{\circ} \mathrm{C}$ overnight in substrate buffer, containing $50 \mathrm{mM}$ Tris- $\mathrm{HCl}$ and $10 \mathrm{mM} \mathrm{CaCl}_{2}$, at $\mathrm{pH} 8.0$ and stained with $0.5 \%$ Coomassie Blue R250 in a $50 \%$ methanol and a $10 \%$ glacial acetic acid for 30 minutes; then de-stained. Upon renaturation of the enzyme, the gelatinases digested the gelatin in the gel, producing clear bands against an intensely stained background. Protein standards were run concurrently and approximate molecular weights were determined by plotting the relative mobilities of known proteins. Gelatinase zymograms were scanned using a CanoScan 9950F Canon scanner at 1200 dpi. The intensity of the bands was evaluated using Silk Scientific Corporation's pixel-based densitometer program (Un-Scan-It, v5.1, 32-bit) at a resolution of 1 Scanner Unit (1/100 dpi) and expressed as a percentage of control.

\subsection{Matrigel Invasion Assay}

Invasion studies were conducted using Matrigel (Becton Dickinson) inserts in 24-well plates. Suspended in me- 
dium, the SC-255 cells were supplemented with the NM and seeded on the insert in the well. Thus, both the medium on the insert and in the well contained the same supplements. The plates with the inserts were then incubated in a culture incubator equilibrated with $95 \%$ room air and $5 \% \mathrm{CO}_{2}$ for 24 hours. After incubation, the media from the wells was drawn. The cells on the upper surface of the inserts were gently scrubbed away with cotton swabs. The cells that had penetrated the Matrigel membrane and migrated onto the lower surface of the Matrigel were stained with Hematoxylin \& Eosin (H\&E) and visually counted under the microscope.

\subsection{Cell Migration}

To study cell migration, a $2 \mathrm{~mm}$ wide single uninterrupted scratch test was made from the top to bottom of the culture plates of SC-255 cells grown to confluence. The culture plates were washed with PBS, incubated with the NM in the medium and tested with $0,50,100,250$, 500 and $1000 \mu \mathrm{g} / \mathrm{ml}$ in triplicate at each dose for 24 hours. The cells were washed with PBS, fixed and stained with $\mathrm{H} \& \mathrm{E}$, and photomicrographs were taken.

\subsection{Morphology and Apoptosis}

The morphology of the cells cultured for 24 hours in test concentrations of the NM were evaluated by $\mathrm{H}$ \& $\mathrm{E}$ staining, observed and photographed by microscopy.

For apoptosis studies the SC-255 cells at near confluence were challenged with the NM dissolved in media at experimental doses and incubated for 24 hours. The cell culture was washed with PBS and treated with the caspase reagent as specified per the manufacturer's protocol (Molecular Probes Image-IT Live Green Poly Caspases Detection Kit 135104, Invitrogen). The cells were photographed under a fluorescent microscope and counted. Green colored cells represent viable cells, yellow and orange colored cells represent early apoptosis, and red colored cells represent late apoptosis.

\subsection{Data Analysis}

The results were expressed as mean \pm S.D. The test data was analyzed by an independent t-test. Significance was determined at $\mathrm{p}<0.05$.

\section{Results}

\subsection{Cell Proliferation of SC-255 Cell Line}

Figure 1 shows the effect of the NM on proliferation at different doses. Doses of the NM ranging from $10-100$ $\mu \mathrm{g} / \mathrm{ml}$ did not have a significant effect on the proliferation. Increasing doses of the NM however exhibited an increasing toxicity. Only 17\% (p < 0.05), and 27\% (p < $0.05)$ of the viable cells were observed at 500 and 1000

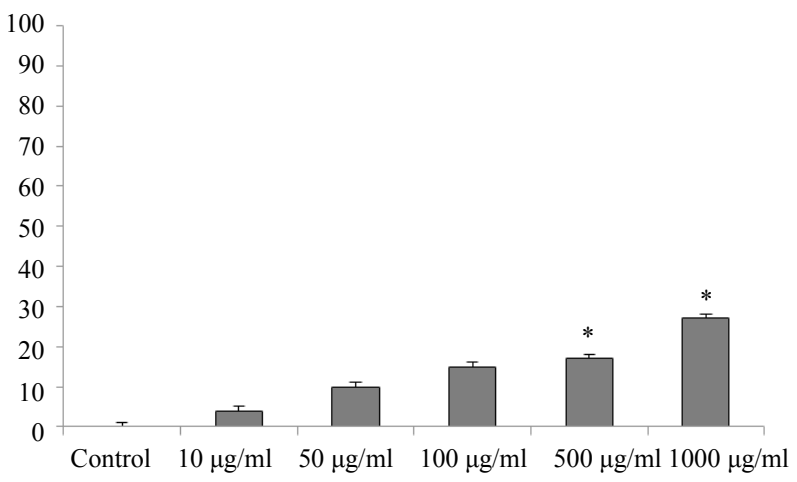

Figure 1. The effect of NM on SC-255 cells toxicity. "The doses 500 and $1000 \mu \mathrm{g} / \mathrm{ml}$ significantly increase the toxicity $(\mathbf{p}<0.05)$.

$\mu \mathrm{g} / \mathrm{ml}$, respectively, as compared to the control group.

\subsection{Gelatinase Zymography}

Figure 2 shows the effect of the NM on the expression of both MMP-2 and MMP-9 production by the SC-255 cells. PMA treatment further induced the expressions of MMP9 (Figure 2(b)). The NM inhibited both MMP-2 and MMP-9 expression in a dose-dependent manner with a total virtual inhibition at $500 \mu \mathrm{g} / \mathrm{ml}$ of NM. Figure 2(c) represents densitometry analysis of inhibition of MMP-2 and MMP-9 secretion for untreated SC-255 cells. The MMP-2 analysis showed $18 \%$ inhibition at $100 \mu \mathrm{g} / \mathrm{ml}$, $95 \%$ and $98 \%$ at 500 and $1000 \mu \mathrm{g} / \mathrm{ml} \mathrm{NM}$. Linear regression analysis showed a linear trend of $\mathrm{R}^{2}=0.80$. Untreated SC-255 cells showed an inhibition of MMP-9 expression of $15 \%$ at $50 \mu \mathrm{g} / \mathrm{ml}, 25 \%$ at $100 \mu \mathrm{g} / \mathrm{ml}, 98 \%$ and $99 \%$ at 500 and $1000 \mu \mathrm{g} / \mathrm{ml}$ of $\mathrm{NM}$, respectively, with $\mathrm{R}^{2}=0.83$ (Figure 2(c)). For SC-255 cells treated with PMA, the MMP-2 inhibition was seen as follows: $9 \%$ at $50 \mu \mathrm{g} / \mathrm{ml}, 7 \%$ at $100 \mu \mathrm{g} / \mathrm{ml}$ and $95 \%$ and $98 \%$ at 500 and $1000 \mu \mathrm{g} / \mathrm{ml}$ concentration of $\mathrm{NM}$, respectively. Regression was noted at $\mathrm{R}^{2}=0.81$. Finally, for the SC255 cells treated with PMA, an equally strong inhibition of expression of MMP-9 was observed. MMP-9 expression was inhibited by $22 \%$ at $50 \mu \mathrm{g} / \mathrm{ml}$ of $\mathrm{NM}, 43 \%$ at $100 \mu \mathrm{g} / \mathrm{ml}$, while $98 \%$ and $99 \%$ at 500 and $1000 \mu \mathrm{g} / \mathrm{ml}$, respectively, $\mathrm{R}^{2}=0.91$ (Figure $2(\mathbf{d})$ ).

\subsection{Matrigel Invasion}

Figures 3(a)-(e) reveals a significant dose-dependent inhibition of SC-255 cell invasion through the Matrigel membrane. A 38\% inhibition was observed at $50 \mu \mathrm{g} / \mathrm{ml}$, $40 \%$ at $100 \mu \mathrm{g} / \mathrm{ml}, 80 \%$ at $500 \mu \mathrm{g} / \mathrm{ml}$, and $100 \%$ inhibition at $1000 \mu \mathrm{g} / \mathrm{ml}$ of the NM, respectively. Figure 3(f) is the analytical representation of Matrigel invasion.

\subsection{Cell Migration}

NM reduced cell migration in a dose dependent manner 


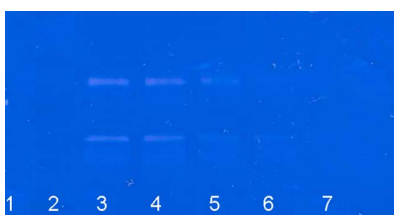

(a)

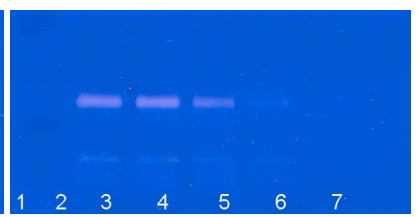

(b)

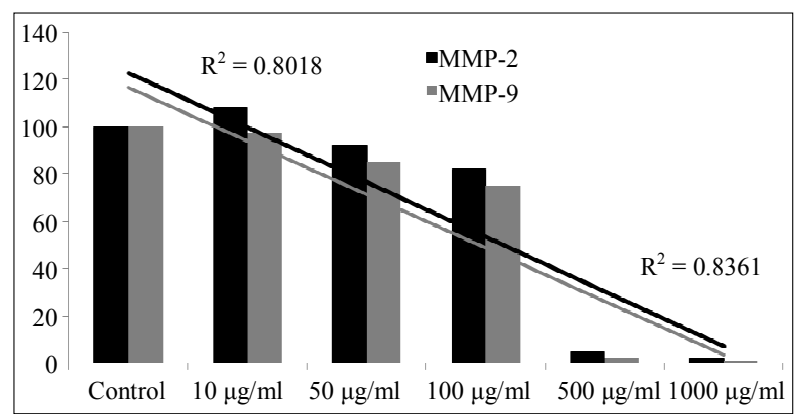

(c)

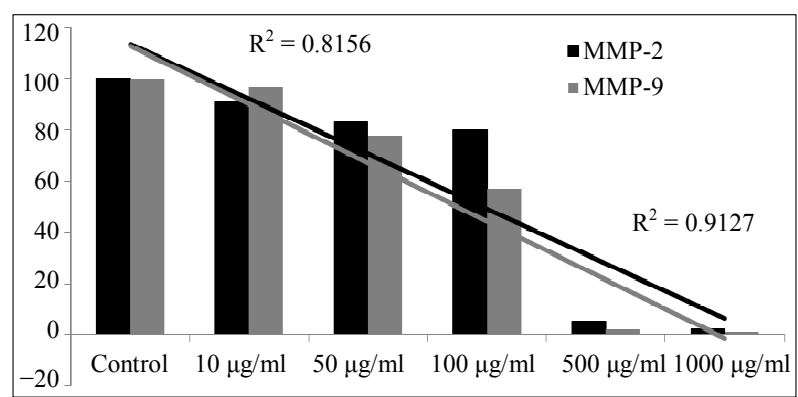

(d)

Figure 2. Effect of NM on MMP-2 and MMP-9 secretion by SC-255 cells. (a) Untreated SC-255 cells; (b) The cells treated with PMA 100 ng/ml (Lane 1: markers; 2: control; 3 - 7: 10, 50, 100, 500, $1000 \mu \mathrm{g} / \mathrm{ml}$ respectively); (c) Densitometry analysis of MMP-2 and MMP-9 secretion by untreated SC255 cells; (d) Effect of PMA and the NM on relative activity of MMP-2, -9 on SC-255 cells.

with a complete block of SC-255 cells at $250 \mu \mathrm{g} / \mathrm{ml}$. Photomicrographs of the results of the scratch test are shown in Figures 4(a)-(e).

\subsection{Morphology (H \& E staining) and Apoptosis}

$\mathrm{H} \& \mathrm{E}$ staining of the SC-255 cells exposed to experimental concentrations of the NM showed no change at the 50 $\mu \mathrm{g} / \mathrm{ml}$ and $100 \mu \mathrm{g} / \mathrm{ml}$ dose. It did however show changes at the 500 and $1000 \mu \mathrm{g} / \mathrm{ml}$ (Figures 5(a)-(e)). These changes include shrinking of the cytoplasm, a darkly stained nuclei and intensely acidophilic cytoplasm-all which suggest cells undergoing apoptosis. Analysis with live green caspase revealed a dose dependent increase in apoptosis of SC-255 cells (Figures 6(a)-(e)). Quantitative analysis of these data (Figure 6(f)) revealed a $51 \%$ apoptotic cells starting at $50 \mu \mathrm{g} / \mathrm{ml}(31 \%$ early and $21 \%$ late stage apoptosis) followed by $71 \%$ at $100 \mu \mathrm{g} / \mathrm{ml}(33 \%$ early and $38 \%$ late stage), simultaneously significant

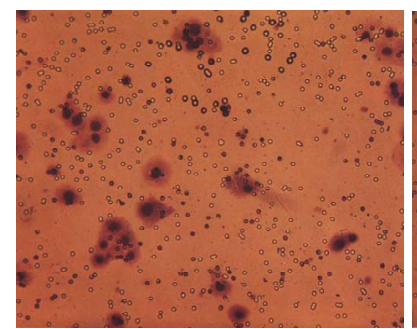

(a)

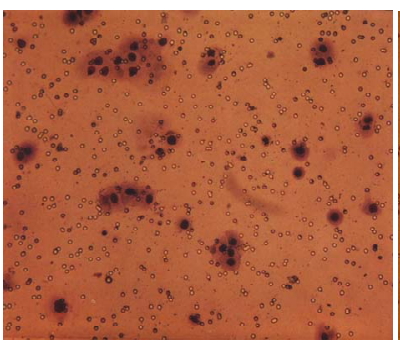

(c)

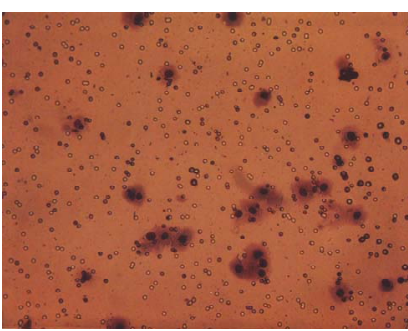

(b)

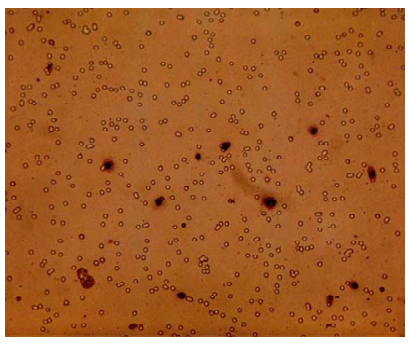

(d)

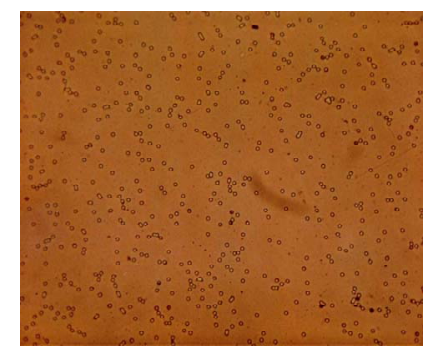

(e)

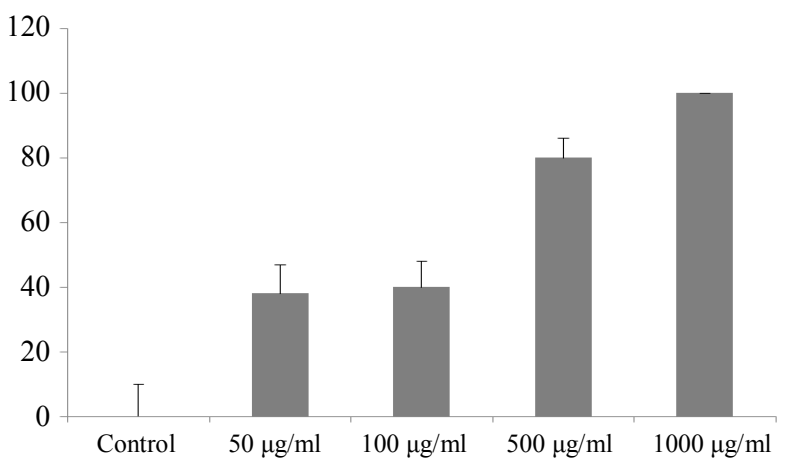

(f)

Figure 3. Effect of the NM on Matrigel invasion by SC-255 cells; (a)-(e) Photomicrographs of the Matrigel invasion with increasing doses of NM: (a) Control; (b) NM $50 \mu \mathrm{g} / \mathrm{ml}$; (c) $100 \mu \mathrm{g} / \mathrm{ml}$; (d) $500 \mu \mathrm{g} / \mathrm{ml}$; (e) $1000 \mu \mathrm{g} / \mathrm{ml}$; (f) Analytical representation of the NM effect on inhibition of Matrigel invasion by SC-255 cells.

decrease in live cells. The increase in late stage apoptotic cells continued as the NM dose increased (reaching $96 \%$ late stage apoptotic cells at $1000 \mu \mathrm{g} / \mathrm{ml}$ ).

\section{Discussion}

In the present study, we investigated the effect of the NM on human malignant tongue cancer cell line SC-255. The 


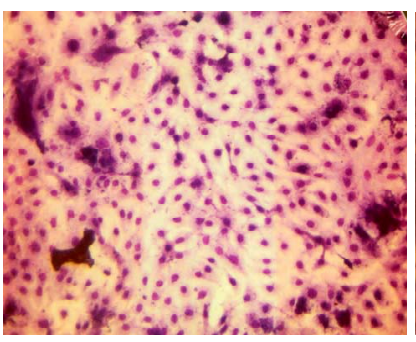

(a)

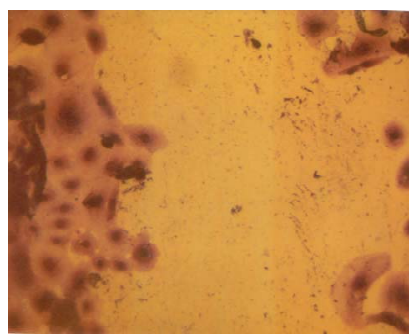

(c)

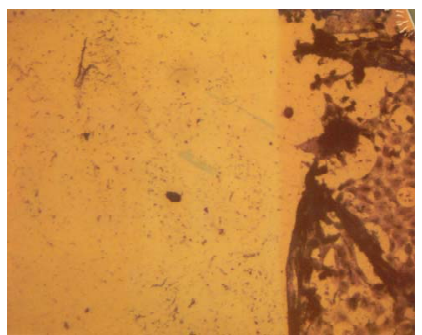

(e)

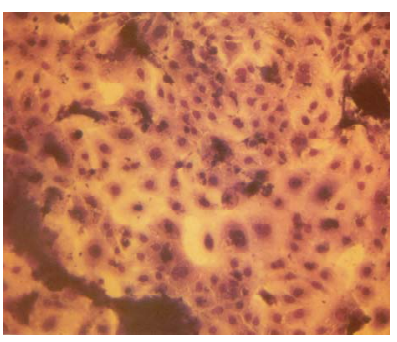

(b)

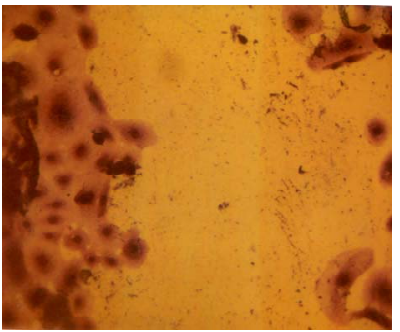

(d)

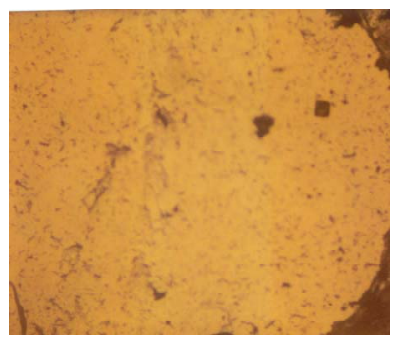

(f)
Figure 4. Photomicrographs demonstrating the effect of NM in SC-255 cell migration. NM reduced the cell migration in a dose dependent manner with complete blockage as observed at $250 \mu \mathrm{g} / \mathrm{ml}$. (a) Control; (b) NM $50 \mu \mathrm{g} / \mathrm{ml}$; (c) $\mathrm{NM} 100 \mu \mathrm{g} / \mathrm{ml}$; (d) NM $250 \mu \mathrm{g} / \mathrm{ml}$; (e) NM $500 \mu \mathrm{g} / \mathrm{ml}$; (f) NM $500 \mu \mathrm{g} / \mathrm{ml}$.

results suggest that NM is effective in inhibiting MMPs production, invasion, and cell migration in a dose-dependent fashion. In addition, the NM also induced apoptosis and caused morphological changes at higher concentrations.

Cancer progression is dependent upon the ability of a malignant cell to migrate beyond its capsule and to induce neovascularization, thereby ensuring its survival and continued proliferation. A tumor size beyond $2 \mathrm{~mm}$ results in hypoxia and acidosis. To maintain its viability, tumor cells must secrete several growth factors to stimulate local blood vessel growth. Invasion of host tissue by cancer cells requires the alteration of cancer cell adhesion, cell migration, and proteolytic degradation of ECM [22].

Since type IV collagen is an integral component of ECM, type IV collagenase, MMP-2 and MMP-9, plays a critical role in tumor invasion [22]. MMPs released by endothelial cells digest the local ECM and thus allow the proliferation of blood vessels. Patel, et al., [23] discov-

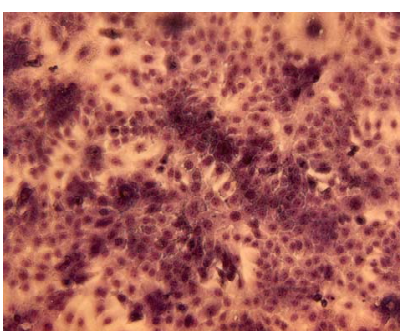

(a)

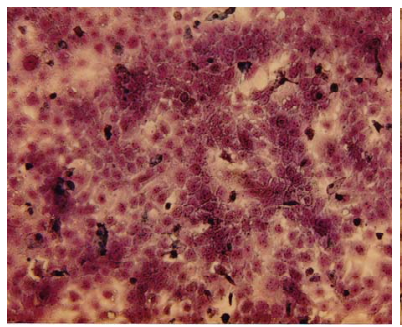

(c)

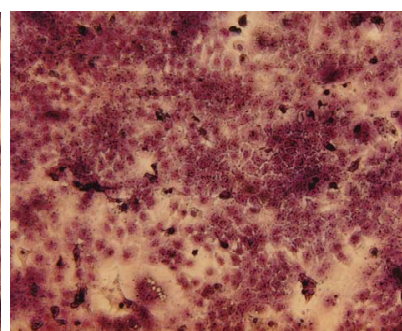

(b)

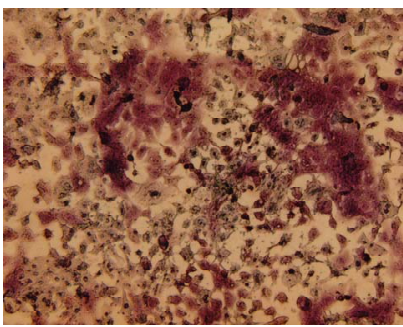

(d)

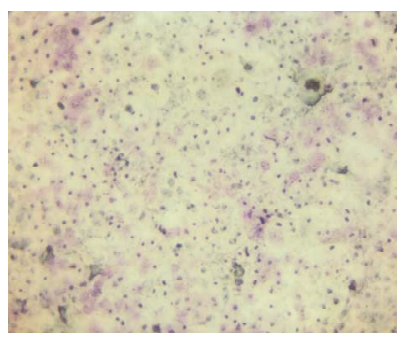

(e)

Figure 5. H \& E staining of tongue carcinoma SC-255 cells exposed to the NM showed slight morphological changes at higher concentrations. (a) Control; (b) $\mathrm{NM} 50 \mu \mathrm{g} / \mathrm{ml}$; (c)

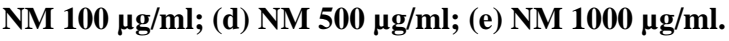

ered that the levels of MMP-2 and MMP-9 were elevated to a significant degree in malignant tissue relative to surrounding normal tissue and MMP-2 was correlated with lymphatic spread. Kawamata discovered increased activity of both pro-MMP-9 and MMP-2 as well as high MMP-2 activity in cancer cell nests within normal gingival tissue. Furthermore, MMP-2 expression was correlated with cancer invasion relative to non-invasive lesions [24]. Up regulation of MMP enzymes has been observed in invasive oral squamous cell carcinoma [25]. Kurahara, et al., determined that MMP-1, -2, -3 and MMP-9 are important determinants of lymph node metastasis [26]. Furthermore, MMP-2 and MMP-9 expression in aggressive cancers is higher than in less aggressive cancers as revealed in the rate of spinal invasion [27]. Thus, it is well known that MMPs are important in the metastatic processes of oral cancers and therefore offer a potential target in intervention.

Our studies demonstrate a significant inhibition of MMPs in tongue cancer cells SC-255 by use of the NM. Additionally, the NM also induced inhibition of cell migration and apoptosis in SC-255 cells. These data suggest 


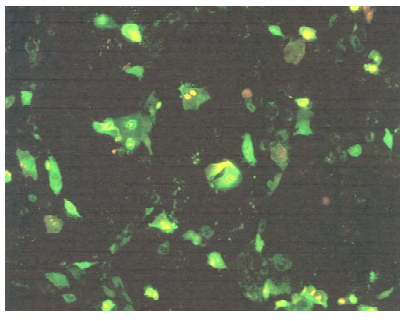

(a)

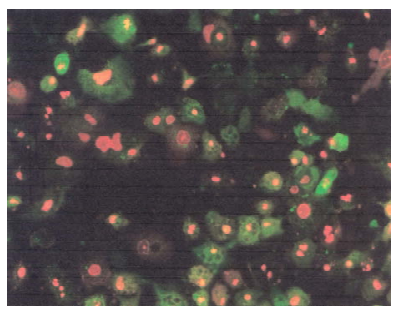

(c)

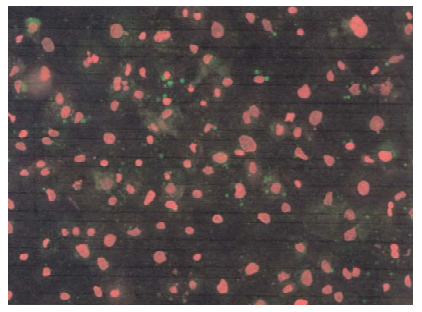

(e)

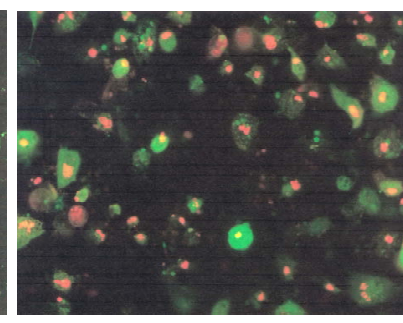

(b)

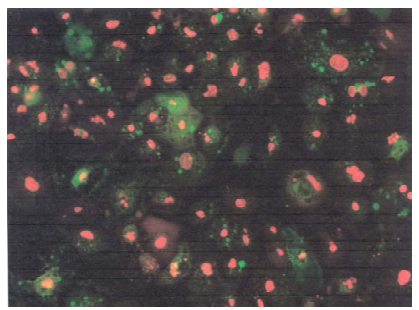

(d)

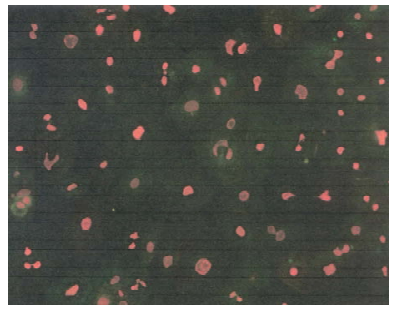

(f)

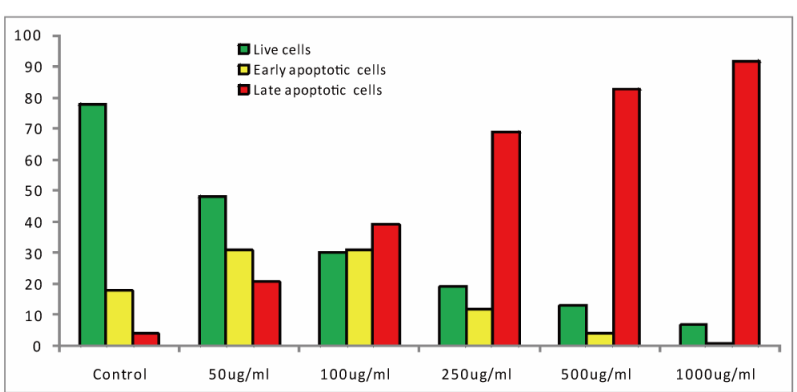

(g)

Figure 6. Effect of the NM on apoptosis induction in SC-255 cells. (a)-(f) Photomicrographs showing apoptosis with increasing doses on NM; (a) Control; (b) NM $50 \mu \mathrm{g} / \mathrm{ml}$; (c) NM $100 \mu \mathrm{g} / \mathrm{ml}$; (d) NM $250 \mu \mathrm{g} / \mathrm{ml}$; (e) NM $500 \mu \mathrm{g} / \mathrm{ml}$; (f) NM $1000 \mu \mathrm{g} / \mathrm{ml}$; (g) Analytical representation of the apoptosis induction.

that the NM could play a significant role in support of oral cancer patients by specifically targeting MMP expression and thereby inhibiting the migration of oral cancer cells within the ECM. Biological agents that prevent ECM degradation by MMPs have shown to be a promising therapeutic approach to cancer.

Furthermore, in contrast to the toxic effects of chemotherapy, the NM has been shown to be a safe therapeutic agent in vivo as well. In a previous study addressing safety issues, we found that gavaging adult female ODS rats (weight $250-300 \mathrm{gm}$ ) with the $\mathrm{NM}$ (at 30, 60, 90 $\mathrm{mg} /$ day for seven days) had neither adverse effects on vital organs, nor on the functional serum enzymes. This indicates that the NM is safe to use even at higher doses, which far exceeded the normal equivalent doses in the NM [28]. NM has also shown in in-vivo studies to suppress acute hepatic toxicity induced by carbon tetrachloride as well as acetaminophen [29,30]. Additionally, NM has shown protective effects against hepatic and nephrotoxicity induced by adriamycin, an antineoplastic antibiotic [31]. Similar protection was also observed when NM was tested against pulmonary and cardiac toxicity induced by Amiodarone, a commonly used anti-arrhythmic agent. Amiodarone is associated with life threatening pulmonary toxicity involving fibrosis and inflammation [32]. These findings suggest that the NM is not only safe, but it also prevents protects vital organs from drug toxicities. Considering the safety, and the protective effects of NM and the results obtained in this study on the tongue cancer cell line, we believe that the nutrition mixture may have a potential for therapeutic support in tongue cancers patients.

\section{Acknowledgements}

Cathy Flowers provided proofreading assistance. Dr. Rath Health Foundation, a not for profit organization, provided research funding.

\section{REFERENCES}

[1] W. J. Blot, J. K. McLaughlin, D. M. Winn, D. F. Austin, R. S. Greenberg, S. Preston-Martin, L. Bernstein, et al. "Smoking and Drinking in Relation to Oral and Pharyngeal Cancer," Cancer Research, Vol. 48, No. 11, 1988, pp. 3282-3287.

[2] S. Y. Choi and H. Kahyo, "Effect of Cigarette Smoking and Alcohol Consumption in the Aetiology of Cancer of the Oral Cavity, Pharynx and Larynx," International Journal of Epidemiology, Vol. 20, No. 4, 1991, pp. 878-885. http://dx.doi.org/10.1093/ije/20.4.878

[3] A. Mashberg, P. Boffetta, R. Winkelman and L. Garfinkel, "Tobacco Smoking, Alcohol Drinking, and Cancer of the Oral Cavity and Oropharynx among US Veterans," Cancer, Vol. 72, No. 4, 1993, pp. 1369-1375. http://dx.doi.org/10.1002/1097-0142(19930815)72:4<136 9::AID-CNCR2820720436>3.0.CO;2-L

[4] C. B. Heffernan, J. P. O’Neill and C. Timon, "Oncogenic Impact of Human Papilloma Virus in Head and Neck Cancer," Journal of Laryngology Otology, Vol. 124, No. 9, 2010, pp. 941-944.

http://dx.doi.org/10.1017/S0022215110001179

[5] P. T. Hennessey, W. H. Westra and J. A. Califano, "Human Papillomavirus and Head and Neck Squamous Cell Carcinoma: Recent Evidence and Clinical Implications," Journal of Dental Research, Vol. 88, No. 4, 2009, pp. 300306. http://dx.doi.org/10.1177/0022034509333371

[6] M. Evans and N. G. Powell, "The Changing Aetiology of 
Head and Neck Cancer: The Role of Human Papillomavirus," Clinical Oncology, Vol. 22, No. 7, 2010, pp. 538-546. http://dx.doi.org/10.1016/j.clon.2010.05.024

[7] C. R. Trivedy, G. Craig and S. Warnakulasuriya, "The Oral Health Consequences of Chewing Areca Nut," Addiction Biology, Vol. 7, No. 1, 2002, pp. 115-125. http://dx.doi.org/10.1080/13556210120091482

[8] M. Bloching, M, W. Reich, J. Schubert, T. Grummt and A. Sandner, "Micronucleus Rate of Buccal Mucosal Epithelial Cells in Relation to Oral Hygiene and Dental Factors," Oral Oncology, Vol. 44, No. 3, 2008, pp. 220-226. http://dx.doi.org/10.1016/j.oraloncology.2007.02.002

[9] N. Taghavi and I. Yazdi, "Type of Food and Risk of Oral Cancer," Archives of Iranian Medicine, Vol. 10, No. 2, 2007, pp. 227-232.

http://dx.doi.org/10.1093/annonc/mdg448

[10] C. Pelucchi, R. Talamini, E. Negri, F. Levi, E. Conti, S. Franceschi and C. La Vecchia, "Folate Intake and Risk of Oral and Pharyngeal Cancer," Annals of Oncology, Vol. 14, No. 11, 2003, pp. 1677-1681.

[11] American Cancer Society, "Oral Cavity and Oropharyngeal Cancer," 2013.

http://www.cancer.org/acs/groups/cid/documents/webcont ent/003128-pdf.pdf

[12] NIDCR, "Oral Cancer 5-Year Survival Rates by Race, Gender, and Stage of Diagnosis," 2004.

[13] R. W. Dolan, C. W. Vaughan and N. Fuleihan, "Symptoms in Early Head and Neck Cancer: An Inadequate Indicator," Otolaryngology Head Neck Surgery, Vol. 119, No. 5, 1998, pp. 463-467. http://dx.doi.org/10.1016/S0194-5998(98)70102-0

[14] M. D. Ellison and B. H. Campbell, "Screening for Cancer of the Head and Neck: Addressing the Problem," Surgical Oncology Clinics of North America, Vol. 8, No. 4, 1999, pp. 725-734.

[15] R. P. Takes, A. Rinaldo, C. E. Silver, J. F. Piccirillo, M. Haigentz Jr., C. Suárez, et al., "Future of the TNM Classification and Staging System in Head and Neck Cancer," Head \& Neck, Vol. 32, No. 2, 2010, pp. 1693-1711. http://dx.doi.org/10.1002/hed.21361

[16] J. S. Greenberg, R. Fowler, J. Gomez, V. Mo, D. Roberts, A. K. El-Naggar, et al., "Extent of Extracapsular Spread: A Critical Prognosticator in Oral Tongue Cancer," Cancer, Vol. 97, No. 6, 2003, pp. 1464-1470.

http://dx.doi.org/10.1002/cncr.11202

[17] M. Rath and L. Pauling, "Plasmin-Induced Proteolysis and the Role of Apoprotein (a), Lysine and Synthetic Analogs," Orthomolecular Medicine, Vol. 7, No. 1, 1992, pp. 17-23.

[18] M. W. Roomi, N. Roomi, V. Ivanov, T. Kalinovsky, A. Niedzwiecki and M. Rath, "Inhibition of Pulmonary Metastasis of Melanoma B16FO Cells in C57BL/6 Mice by a Nutrient Mixture Consisting of Ascorbic Acid, Lysine, Proline, Arginine, and Green Tea Extract," Experimental Lung Research, Vol. 32, No. 10, 2006, pp. 517-30. http://dx.doi.org/10.1080/01902140601098552

[19] M. W. Roomi, T. Kalinovsky, N. W. Roomi, A. Niedzwiecki and M. Rath, "Inhibition of SK-N-MC Human
Neuroblastoma Cell Line in Vivo and in Vitro by a Novel Nutrient Mixture," Oncology Reports, Vol. 29, No. 5, 2013, pp. 1714-1720

[20] M. W. Roomi, V. Ivanov, S. Netke, T. Kalinovsky, A. Niedzwiecki and M. Rath, "In Vivo and in Vitro Antitumor Effect of Ascorbic Acid, Lysine, Proline and Green Tea Extract on Human Melanoma Cell Line A2058," In Vivo, Vol. 20, No. 1, 2006, pp. 25-32.

[21] M. W. Roomi, N. Roomi, V. Ivanov, T. Kalinovsky, A. Niedzwiecki and M. Rath, "Inhibitory Effect of a Mixture Containing Ascorbic Acid, Lysine, Proline and Green Tea Extract on Critical Parameters in Angiogenesis," Oncology Reports, Vol. 14, No. 4, 2005, pp. 807-815.

[22] D. Bourboulia and W. G. Stetler-Stevenson,"Matrix Metalloproteinases (MMPs) and Tissue Inhibitors of Metalloproteinases (TIMPs): Positive and Negative Regulators in Tumor Cell Adhesion," Seminars in Cancer Biology, Vol. 20, No. 3, 2010, pp. 161-168.

http://dx.doi.org/10.1016/j.semcancer.2010.05.002

[23] B. P. Patel, S. V. Shah, S. N. Shukla, P. M. Shah and P. S. Patel, "Clinical Significance of MMP-2 and MMP-9 in Patients with Oral Cancer," Head Neck, Vol. 29, No. 6, 2007, pp. 564-572. http://dx.doi.org/10.1002/hed.20561

[24] H. Kawamata, D. Uchida, H. Hamano, T. Kimura-Yanagawa, K. I. Nakashiro, S. Hino, F. Omotehara, H. Yoshida and M. Sato, "Active-MMP2 in Cancer Cell Nests of Oral Cancer Patients: Correlation with Lymph Node Metastasis," International Journal of Oncology, Vol. 13, No. 4, 1998, pp. 699-704.

[25] M. Sutinen, T. Kainulainen, T. Hurskainen, E. Vesterlund, J. P. Alexander, C. M. Overall, et al., "Expression of Matrix Metalloproteinases (MMP-1 and -2) and Their Inhibitors (TIMP-1, -2 and -3) in Oral Lichen Planus, Dysplasia, Squamous Cell Carcinoma and Lymph Node Metastasis," British Journal of Cancer, Vol. 77, No. 12, 1998, pp. 2239-2245. http://dx.doi.org/10.1038/bjc.1998.372

[26] S. Kurahara, M. Shinohara, T. Ikebe, S. Nakamura, M. Beppu, A. Hiraki, et al., "Expression of MMPS, MT-MMP, and TIMPs in Squamous Cell Carcinoma of the Oral Cavity: Correlations with Tumor Invasion and Metastasis," Head Neck, Vol. 21, No. 7, 1999, pp. 627-638. http://dx.doi.org/10.1002/(SICI)1097-0347(199910)21:7< 627::AID-HED7>3.0.CO;2-2

[27] Z. L. Gokaslan, S. K. Chintala, J. E. York, V. Boyapati, S. Jasti, R. Sawaya, et al., "Expression and Role of Matrix Metalloproteinases MMP-2 and MMP-9 in Human Spinal Column Tumors," Clinical and Experimental Metastasis, Vol. 16, No. 8, 1998, pp. 721-728. http://dx.doi.org/10.1023/A:1006580728338

[28] M. W. Roomi, V. Ivanov, S. P. Netke, A. Niedzwiecki, M. Rath, "Serum Markers of the Liver, Heart, and Kidney and Lipid Profile and Histopathology in ODS Rats Treated with Nutrient Synergy," Journal of the American College of Nutrition, Vol. 22, No. 5, 2003, p. 477.

[29] M. W. Roomi, T. Kalinovsky, N. W. Roomi, V. Ivanov, M. Rath, A. Niedzwiecki, "A Nutrient Mixture Suppresses Carbon Tetrachloride-Induced Acute Hepatic Toxicity in ICR Mice," Human and Experimental Toxicology, Vol. 
22, No. 7, 2008, pp. 559-566.

http://dx.doi.org/10.1177/0960327108096851

[30] M. W. Roomi, T. Kalinovsky, V. Ivanov, M. Rath, A. A. Niedzwiecki, "A Nutrient Mixture Prevents Acetaminophen Hepatic and Renal Toxicity in ICR Mice," Human and Experimental Toxicology, Vol. 27, No. 3, 2008, pp. 223-230. http://dx.doi.org/10.1177/0960327108090276

[31] M. W. Roomi, N. W. Roomi, M. Rath and A. Niedzwiecki, "Prevention of Adriamycin Hepatic and Renal
Toxicity in Male BALB/c Mice by a Nutrient Mixture," Presented at the 50th Annual Meeting of Society of Toxicology, March 2011, p. 476.

[32] M. W. Roomi, N. W. Roomi, M. Rath and A. Niedzwiecki, "Prevention of Amiodarone-Induced Pulmonary and Cardiac Toxicity in Male BALB/c Mice by a Nutrient Mixture," Presented at the 51st Annual Meeting of Society of Toxicology, San Francisco, 11-15 March 2012, Abstract \#2413. 